\title{
Fatty Liver and Impaired Hepatic Metabolism Alter the Congener- specific Distribution of Polychlorinated Biphenyls (PCBs) in Mice with A Liver-specific Deletion of Cytochrome P450 Reductase
}

\author{
Xueshu Li ${ }^{1}$, Chunyun Zhang ${ }^{1}$, Kai Wang ${ }^{2}$, Hans-Joachim Lehmler ${ }^{1}$ \\ ${ }^{1}$ Department of Occupational and Environmental Health, College of Public Health, University of \\ lowa, lowa City, IA 52242, USA; \\ ${ }^{2}$ Department of Biostatistics, College of Public Health, University of lowa, lowa City, IA 52242, \\ USA
}

\section{Abstract}

Polychlorinated biphenyls (PCBs) are persistent organic pollutants that are linked to adverse health outcomes. PCB tissue levels are determinants of PCB toxicity; however, it is unclear how factors, such as an altered metabolism and/or a fatty liver, affect PCB distribution in vivo. We determined the congener-specific disposition of PCBs in mice with a liver-specific deletion of cytochrome P450 reductase (KO), a model of fatty liver with impaired hepatic metabolism, and wild-type (WT) mice. Eight-week-old male WT ( $\left.\mathrm{M}_{\mathrm{WT}}, \mathrm{n}=3\right)$, male $\mathrm{KO}\left(\mathrm{M}_{\mathrm{KO}}, \mathrm{n}=5\right)$, female WT ( $\left.\mathrm{F}_{\mathrm{WT}}, \mathrm{n}=4\right)$, and female $\mathrm{KO}$ mice $\left(\mathrm{F}_{\mathrm{KO}}, \mathrm{n}=4\right)$ were exposed orally to Aroclor 1254. PCBs were quantified in adipose, blood, brain, and liver tissues by gas chromatography-mass spectrometry. The $\Sigma \mathrm{PCB}$ levels followed the rank order adipose $>$ liver $\sim$ brain $>$ blood in WT and adipose $\sim$ liver $>$ brain $>$ blood in KO mice. PCB levels were much higher in the liver of KO than WT mice, irrespective of the sex. A comparison across exposure groups revealed minor genotype and sex-dependent differences in the PCB congener profiles ( $\cos \Theta>0.92)$. Within each exposure group, tissue profiles showed small differences between tissues ( $\cos \Theta=0.85$ to 0.98 ). These differences were due to a decrease in metabolically more labile PCB congeners and an increase in congeners resistant to metabolism. The tissue-to-blood ratio of PCBs decreased for adipose, increased for the brain, and remained constant for the liver with an increase in chlorination. While these ratios did

\footnotetext{
Corresponding Author: Dr. Hans-Joachim Lehmler, The University of Iowa, Department of Occupational and Environmental Health, University of Iowa Research Park, \#221 IREH, Iowa City, IA 52242-5000, Phone: (319) 335-4981, Fax: (319) 335-4290, hansjoachim-lehmler@uiowa.edu.

Author contributions

Li: Conceptualization; Data curation; Formal analysis; Investigation; Methodology; Validation; Visualization; Roles/Writing - original draft; Writing - review \& editing. Zhang: Formal analysis; Investigation; Methodology; Validation; Writing - review \& editing. Wang: Formal analysis; Methodology; Validation; Visualization; Writing - review \& editing. Lehmler: Conceptualization; Data curation; Formal analysis; Funding acquisition; Project administration; Supervision; Validation; Visualization; Roles/Writing - original draft; Writing - review \& editing.

Publisher's Disclaimer: This is a PDF file of an unedited manuscript that has been accepted for publication. As a service to our customers we are providing this early version of the manuscript. The manuscript will undergo copyediting, typesetting, and review of the resulting proof before it is published in its final form. Please note that during the production process errors may be discovered which could affect the content, and all legal disclaimers that apply to the journal pertain.

Declaration of interests

The authors declare that they have no known competing financial interests or personal relationships that could have appeared to influence the work reported in this paper.
} 
not follow the trends predicted using a composition-based model, the agreement between experimental and calculated partition coefficients was reasonable. Although the distribution of PCBs differs between KO and WT mice, the magnitude of the partitioning of PCBs from the blood into tissues can be approximated using composition-based models.

\section{Graphical Abstract}

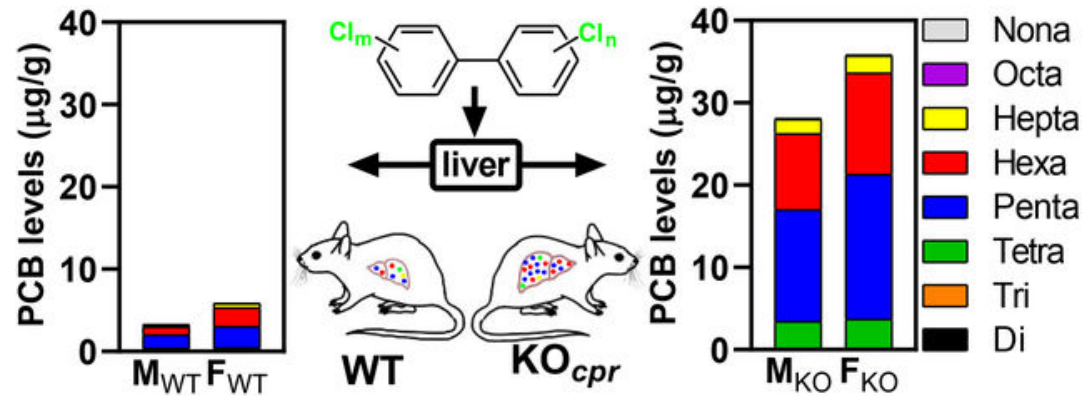

\section{Capsule:}

Mice with a liver-specific deletion of cytochrome P450 reductase display an altered congenerspecific distribution of PCBs due to a fatty liver and impaired hepatic metabolism.

\section{Keywords}

composition-based model; disposition; tissue to blood partition coefficients; persistent organic pollutants; transgenic mice

\section{Introduction}

Exposure to polychlorinated biphenyls (PCBs), a group of 209 persistent organic pollutants, is associated with adverse human health effects, including cancer, developmental neurotoxicity, and effects on the immune system (ATSDR, 2000). Individual PCB congeners can selectively affect a myriad of cellular targets in humans (Pencikova et al., 2018; Sethi et al., 2019); however, humans are exposed to complex mixtures of $>150$ PCB congeners via the diet, dermally or by inhalation (Ampleman et al., 2015; ATSDR, 2000; Chen et al., 2017; Schecter et al., 2010). Moreover, occupational exposures to PCBs remain a concern (Haga et al., 2018). In contrast, in vitro and in vivo studies of PCBs typically employ individual congeners or simplified and technical PCB mixtures. The disposition of individual PCBs in laboratory animals, especially after oral exposure, is well investigated. Several studies also report the tissue distribution of PCBs after inhalation exposure in rats (Hu et al., 2010; Hu et al., 2012; Hu et al., 2013). In mammals and other species, many PCB congeners are oxidized by hepatic and extrahepatic cytochrome $\mathrm{P} 450$ enzymes to hydroxylated metabolites $(\mathrm{OH}-$ PCBs) (Grimm et al., 2015). These metabolites can undergo further biotransformation to, for example, dihydroxylated metabolites, sulfate and glucuronide conjugates, and other PCB metabolites and, depending on the degree of chlorination are excreted with the feces or urine (Birnbaum, 1985). 
Toxicokinetic models have been developed for individual PCB congeners or simple PCB mixture in rodent models following oral (Kania-Korwel et al., 2012; Kania-Korwel et al., 2010) and intravenous exposure (Birnbaum, 1983; Lutz et al., 1984). These studies provide insights into the levels of PCBs in target tissues, such as the adipose tissue, blood, liver, or brain, thus allowing the translation of results from toxicity studies with PCBs to humans. As a rule of thumb, PCB levels are directly proportional to the fat content of a tissue, and, in wild-type rodents, follow the general order adipose > liver > brain > blood (Kania-Korwel et al., 2005; Milanowski et al., 2010; Weisbrod et al., 2000). However, the partitioning of PCBs from the blood into tissues can differ from this general trend, depending on the animal model, the experimental design, or other factors.

A number of computational models have been developed to predict the partition coefficients in tissues in the absence of experimental data, including tissue composition-based models (Endo et al., 2013; Schmitt, 2008). These models use readily available information, including the quantities of the biological components (e.g., lipids, protein, and water) in tissues and the partition coefficients of PCBs (e.g., lipid/water partitioning coefficient), to estimate the distribution of PCBs in vivo. For example, a PP-LFER-composition-based model was adopted to determine the liver : blood partitioning coefficients of mono- to hexachlorinated PCBs and the adipose : plasma partition coefficients of di- to octachlorinated PCBs in rats (Endo et al., 2013). This model can be used to predict the partitioning of PCBs between animal tissues of interest for all PCB congeners with published Abraham solvation parameters (van Noort et al., 2010) and established PP-LFERs describing the correlations between the chemical descriptors and tissue/water partition coefficients (Endo et al., 2012; Endo et al., 2011; Endo and Goss, 2011; Geisler et al., 2012). Moreover, this model can estimate the tissue : blood partitioning of PCBs in animal models that the quantities of the biological components are altered due to genetic or environmental factors.

Factors affecting the tissue : blood partitioning of PCBs include an altered (hepatic) metabolism and redistribution away from the site of metabolism to tissues with a high-fat content (Birnbaum, 1983; Soontornchat et al., 1994). The induction of hepatic cytochrome P450 enzymes will more rapidly eliminate episodic and some persistent PCB congeners (Imsilp and Hansen, 2005). In sub-chronic studies, growth dilution can contribute to the distribution of PCBs (Hansen and Welborn, 1977). Also, changes in the composition of body compartments can shift the distribution of PCBs. Starvation shifts the partitioning of PCB 153 from adipose to other tissues (Wyss et al., 1982). Similarly, PCB 153 is mobilized from fat tissues during lactation and redistributed to the breast milk (Spindler-Vomachka and Vodicnik, 1984). Fatty liver caused by exposure to PCB 126 produces a redistribution of PCBs from the adipose tissue to the liver (Chu et al., 1994; Van Birgelen et al., 1994). Similarly, fatty liver induced by a high-fat diet is expected to result in the sequestration of PCBs in the mouse liver, a process that may underly the obesogenic effects of PCBs (Wahlang et al., 2013; Wahlang et al., 2014). Moreover, transgenic animals can have body weights or tissue compositions that differ from wild-type animals and affect PCB disposition (Milanowski et al., 2010; Wu et al., 2015; Wu et al., 2020). 
The objective of the present study was to determine how a fatty liver and an impaired hepatic PCB metabolism alters the PCB congener profiles in target tissues following exposure to a complex PCB mixture. PCB congener profiles, levels, and tissue : blood ratios were determined in adipose tissue, blood, brain, and liver in male and female $\mathrm{KO}$ and congenic WT mice exposed to a complex PCB mixture. The KO mouse model displays an impaired hepatic xenobiotic metabolism and a fatty liver with altered fatty acid profiles (Gu et al., 2005; Weng et al., 2005). Aroclor 1254 was selected for this study because the disposition and toxicity of this technical PCB mixture are well characterized (ATSDR, 2000). Moreover, Aroclor 1254 contains PCB 91 and PCB 136 (Frame, 1997). The disposition and toxicokinetics of both PCB congeners have been studied in $\mathrm{KO}$ and congenic WT mice after a single oral exposure to the individual PCB congeners ( $\mathrm{Li}$ et al., 2019; Wu et al., 2015; Wu et al., 2020). We adopted a comparable study design to facilitate comparison across studies.

\section{Materials and Methods}

\subsection{Chemicals and Reagents}

Aroclor 1254 (lot \#: KB 05-612) was provided by Dr. Larry Hansen. A detailed characterization of this Aroclor 1254 batch has been reported previously (Zhao et al., 2010). Additional information regarding other chemicals and reagents is provided in the supplementary material.

\subsection{Animal exposures}

Alb-Cre ${ }^{+/-} / \mathrm{Cpr}^{\text {lox }+/+}$ mice with a liver-specific deletion of the cytochrome $\mathrm{P} 450$ oxidoreductase (EC 1.6.2.4) gene (KO) and congenic Alb-Cre ${ }^{-/-} / \mathrm{Cpr}^{\mathrm{lox}+/+}$ (WT) mice were obtained from Dr. Xinxin Ding (University of Arizona, AZ, USA) to establish a breeding colony at the University of Iowa (Gu et al., 2003; Wu et al., 2003). Details regarding the maintenance of the breeding colony are provided in the supplementary material. The Institutional Animal Care and Use Committee of the University of Iowa approved all animal procedures (protocol \#: 1206120). Daily animal welfare-assessments were performed by laboratory personnel, and no adverse outcomes were observed throughout the study. Eightweek-old mice were randomly divided into four exposure groups, including male WT ( $\mathrm{M}_{\mathrm{WT}}$, $\mathrm{n}=3)$, male $\mathrm{KO}\left(\mathrm{M}_{\mathrm{KO}}, \mathrm{n}=5\right)$, female WT $\left(\mathrm{F}_{\mathrm{WT}}, \mathrm{n}=4\right)$, and female $\mathrm{KO}\left(\mathrm{F}_{\mathrm{KO}}, \mathrm{n}=4\right)$. The animals were exposed around 9 am once by oral gavage to Aroclor $1254(16 \mathrm{mg} / \mathrm{kg}$ body weight in corn oil, $10 \mathrm{~mL} / \mathrm{kg}$ body weight), respectively. This acute dosing paradigm lays the groundwork for future toxicokinetic studies. The dose was selected based on a previous animal study and ensured a robust detection of PCBs in target tissues (Kania-Korwel et al., 2005). In parallel, animals $(\mathrm{n}=3)$ were exposed to corn oil $(10 \mathrm{~mL} / \mathrm{kg}$ body weight $)$ alone to assess the background contamination of the animals. The animals were euthanized $24 \mathrm{~h}$ after PCB exposure by carbon dioxide asphyxiation followed by thoracotomy and the removal of vital organs as confirmation of death. Whole blood was collected by cardiac puncture and stored at $-20^{\circ} \mathrm{C}$ in glass tubes with $80 \mu \mathrm{L}$ of ethylenediaminetetraacetic acid solution (EDTA, 7.5\% w/w). Tissues (abdominal adipose tissue, brain, and liver) were collected and stored at $-80^{\circ} \mathrm{C}$. 


\subsection{PCB extraction}

PCBs were extracted from adipose $(0.05-0.09 \mathrm{~g})$, brain $(0.10-0.15)$, liver $(0.06-0.18 \mathrm{~g})$ and blood $(0.55-0.73 \mathrm{~g})$ with a pressurized liquid extraction method (Kania-Korwel et al., 2007; Wu et al., 2015) on the Dionex ASE200 system (Dionex, Sunnyvale, CA, USA). Extraction cells $(33 \mathrm{~mL})$ loaded with pre-combusted Florisil (12 g) and diatomaceous earth (DE, $2 \mathrm{~g}$ ) were extracted with a mixture of hexane and acetone $(1: 1, \mathrm{v} / \mathrm{v})$ on an ASE200 at $100{ }^{\circ} \mathrm{C}$ and $1500 \mathrm{psi}(10 \mathrm{MPa})$ with preheat equilibration for $6 \mathrm{~min}, 60 \%$ of cell flush volume, and 1 static cycle of $5 \mathrm{~min}$. The tissue was homogenized with the top DE layer, and the DE-tissue mixture was placed back into the extraction cell. Blood samples were loaded directly onto the cellulose filter of the cell. Surrogate standards, $\mathrm{d}_{5}$-PCB 30 and $\mathrm{d}_{5}$-PCB 65 (80 ng each), were added to every sample before the extraction. The cells were extracted with the same parameters described above. The extracts were concentrated to $\sim 0.5 \mathrm{~mL}$ on a TurboVap II (Biotage LLC, NC, USA), transferred to a pre-combusted tube, and treated with $2 \mathrm{~mL}$ of concentrated sulfuric acid for lipid removal. The extract was transferred to a new glass tube, evaporated under a gentle stream of nitrogen to $\sim 50 \mu \mathrm{L}$, and transferred to a gas chromatography vial. The internal standards (volume correctors), ${ }^{13} \mathrm{C}_{12}$-PCB 9 and ${ }^{13} \mathrm{C}_{12^{-}}$ PCB 194 (50 ng each), were spiked to every sample before analysis.

\subsection{Gas chromatographic determinations}

Samples were analyzed using an Agilent 7890A gas chromatograph coupled with an Agilent 5975C Inert Mass Selective Detector (MSD) operated in electronic ionization mode. An SLB-5MS capillary GC column (30 m length, $250 \mu \mathrm{m}$ inner diameter, $0.25 \mu \mathrm{m}$ film thickness; Supelco, Bellefonte, PA, USA) was used in the select ion monitoring (SIM) mode (Holland et al., 2016; Hu et al., 2015; Li et al., 2018). The temperature program was as follows: $80^{\circ} \mathrm{C}$, hold for $1 \mathrm{~min}, 2^{\circ} \mathrm{C} / \mathrm{min}$ to $160^{\circ} \mathrm{C} / \mathrm{min}, 1^{\circ} \mathrm{C} / \mathrm{min}$ to $170{ }^{\circ} \mathrm{C}$, hold for $15 \mathrm{~min}$, $1{ }^{\circ} \mathrm{C} / \mathrm{min}$ to $180{ }^{\circ} \mathrm{C}$, hold for $15 \mathrm{~min}, 1{ }^{\circ} \mathrm{C} / \mathrm{min}$ to $245^{\circ} \mathrm{C}$, t10 ${ }^{\circ} \mathrm{C} / \mathrm{min}$ to $300{ }^{\circ} \mathrm{C}$, and hold for $15 \mathrm{~min}$. The injector temperature was $280^{\circ} \mathrm{C}$, and the operating temperatures were $280{ }^{\circ} \mathrm{C}$, $230{ }^{\circ} \mathrm{C}$ and $150{ }^{\circ} \mathrm{C}$ for transfer line, source, and quadrupole, respectively. The flow rate of carrier gas helium was $1.1 \mathrm{~mL} / \mathrm{min}$. By this congener specific method, 162 individual or coeluting peaks of PCBs can be separated and quantified. Twenty-eight channels were set up in GC-MS SIM mode (Table S1). The MSD was linear over the concentration range encountered in this study (Table S2). Datasets with quality assurance/quality control data (i.e., results from all method blanks, tissue blanks, and ongoing recovery and precision standards analyzed in parallel with all samples) and data for individual animals are openly available in Iowa Research Online at http://doi.org/10.25820/data.006117 (Li et al., 2020). For Figures with PCB congener profiles, see Figs. S1-S4. The peak corresponding to PCB 138, PCB 158, PCB 163, and PCB 164 is abbreviated as PCB 138 throughout the manuscript.

\subsection{Model prediction of the tissue-blood partitioning of PCBs}

A composition-based model (Endo et al., 2013) was used for the prediction of the partition coefficients of PCBs between tissues and whole blood. In this model, tissues and blood are assumed to contain five biological components, including albumin, muscle protein, membrane lipid, storage lipid, and water. The volume fractions and lipid content of all 
biological components, both in tissues and blood, were taken from published experimental values (Table S3) (Endo et al., 2013; Schmitt, 2008; Wu et al., 2015). The partitioning of PCBs between the biological components was determined with published Abraham solvation parameters (van Noort et al., 2010) and polyparameter linear free energy relationships (PP-LFERs) describing the correlations between the chemical descriptors and tissue/water partition coefficients (Endo et al., 2012; Endo et al., 2011; Endo and Goss, 2011; Geisler et al., 2012). The equation used for the calculations of tissue-blood partitioning coefficients ( $\left.K_{\text {tissue/blood }}\right)$ were as follows (Endo et al., 2013):

$$
\begin{aligned}
& K_{\text {tissuelblood }}=\frac{K_{\text {tissue/water }}}{K_{\text {blood/water }}} \\
& =\frac{K_{a p / w} f_{a p}^{\text {tissue }}+K_{m p / w} f_{m p}^{t i s s u e}+K_{\text {sl/w }} f_{s l}^{\text {tissue }}+K_{m l / w} f_{m l}^{\text {tissue }}+f_{w}^{\text {tissue }}}{K_{a p / w} f_{a p}^{\text {blood }}+K_{m p / w} f_{m p}^{\text {blood }}+K_{\text {sl } / w} f_{s l}^{\text {blood }}+K_{m l / w} f_{m l}^{\text {blood }}+f_{w}^{\text {blood }}}
\end{aligned}
$$

Where $K_{\text {tissue/water }}$ and $K_{\text {blood/water }}$ are the partition coefficients of PCBs between tissue and water and between blood and water, respectively. $K_{a p / w}, K_{m p / w}, K_{s / / w}$ and $K_{m l / w}$ are the partition coefficients of PCBs between albumin protein and water, muscle protein and water, storage lipid and water, and membrane lipid and water, respectively. $f_{a p}^{t i s s u e}, f_{m p}^{t i s s u e}, f_{s l}^{\text {tissue }}$, $f_{m l}^{t i s s u e}$ and $f_{w}^{t i s s u e}$ are the volume fractions of albumin protein, muscle protein, storage lipid, membrane lipid, and water in tissue, respectively. $f_{a p}^{\text {blood }}, f_{m p}^{\text {blood }}, f_{s l}^{\text {blood }}, f_{m l}^{\text {blood }}$ and $f_{w}^{b l o o d}$ are the volume fractions of albumin protein, muscle protein, storage lipid, membrane lipid, and water in the blood, respectively.

\subsection{Data visualization and statistical analysis}

PCB mass percentages and wet weight-adjusted tissue levels are presented as mean \pm standard deviation (Tables S4-S9). Median values are provided for experimental tissue partition coefficients. Differences in PCBs congener profiles were analyzed and visualized using the Heatmap function and Sparse partial least squares-discriminant analysis (sPLSDA), as implement by MetaboAnalyst 4.0 (Chong et al., 2018). Significant differences between exposure groups were analyzes using Student's t-test (Tables S10-S13). Two-way ANOVA was used to compare the PCB profiles, based on tissue levels, with respect to homolog group, Class, or congener between sex or genotypes. If the interaction term, for instance, between classes and sex, is significant, then the profiles on classes are different between sex (Table S14). These analyses were performed with R (version 3.6.3). Similarity coefficients $\cos \Theta$ comparing average congener profiles (Tables S15-S17) were calculated are described (Davis, 1986). The similarity coefficient uses the cosine of the angle between two multivariable vectors, such as PCB profiles). A value of 0.0 describes two completely different profiles, and 1.0 describes two identical profiles.

\section{Results and Discussion}

\subsection{Levels of total PCBs ( $\mathrm{PCB})$ in tissues}

In WT mice, the $\Sigma$ PCB levels followed the rank order adipose $>$ liver $\sim$ brain $>$ blood (Fig.

1). This rank order is consistent with earlier studies reporting an accumulation of PCBs and 
related organochlorines in fat-rich organs from different mammalian species (Kania-Korwel et al., 2005; Milanowski et al., 2010; Weisbrod et al., 2000). In KO mice, the $\Sigma$ PCB levels in adipose and liver tissue followed the rank order adipose $\sim$ liver $>$ brain $>$ blood. Similar trends were observed when tissue levels of individual PCB congeners (i.e., PCB 91 and PCB 136) were compared across tissues in WT or KO mice exposed to either Aroclor 1254 (Fig. S5), PCB 91 or PCB 136 (Wu et al., 2015; Wu et al., 2020).

An enrichment of $\Sigma \mathrm{PCB}$ was observed in the liver of KO compared to WT mice, irrespective of the sex ( $\mathrm{M}_{\mathrm{WT}}$ vs. $\mathrm{M}_{\mathrm{KO}}, p=0.0010 ; \mathrm{F}_{\mathrm{WT}}$ vs. $\mathrm{F}_{\mathrm{KO}}, p=0.0004$; Table $\left.\mathrm{S} 10\right)$. An enrichment of PCBs in the liver of KO mice was also observed when PCBs were analyzed on a homolog, Class, or congener basis, as discussed below. Similarly, an accumulation of PCB in the liver was observed in disposition studies of single PCB congener in KO and WT mice (Wu et al., 2015; Wu et al., 2020). The accumulation of PCBs in the liver of KO mice is a consequence of the higher lipid content and the elevated protein levels in the liver of KO compared to WT mice (Weng et al., 2005; Wu et al., 2015). The higher lipid content in the liver of KO mice is caused by an impaired hepatic fat metabolism (Gu et al., 2005; Weng et al., 2005). In addition to an increased lipid content in the liver, the expression of hepatic proteins that bind PCBs, such as cytochrome P450 enzymes (Kania-Korwel et al., 2008; Kennedy et al., 1981), is increased in the liver to compensate for the liver-specific deletion of $\operatorname{cpr}$ (Gu et al., 2003). Dioxin-like PCBs and structurally related compounds are sequestered in the liver because they bind to particular cytochrome P450 isoforms (Chen et al., 2003; Diliberto et al., 1999). It is likely that cytochrome P450 enzymes in the liver from KO mice bind PCBs in the absence of metabolic conversion, thus contributing to the hepatic accumulation of PCBs in KO mice.

\subsection{Comparison of PCB homologs, Classes, and congeners across exposure groups}

\subsubsection{Distribution of $\mathrm{PCB}$ homologs in tissues from different exposure} groups and Aroclor 1254-The homolog composition of the PCB residues from blood, brain, and liver, but not adipose tissue, showed differences compared to the homolog composition of Aroclor 1254 (Table S4). Typically, the percentage of lower chlorinated homologs decreased, whereas the percentage of higher chlorinated homologs increased in these tissues compared to Aroclor 1254. Different shifts in the homolog composition were observed for WT compared to KO mice. For example, hexachlorinated PCBs were the major constituents in the brain from $\mathrm{F}_{\mathrm{WT}}$ mice, whereas pentachlorinated PCBs are the major homolog group in Aroclor 1254 (Table S4).

PCB homolog profiles expressed on a tissue wet weight basis (Fig. 1 and Table S7), or as a weight percentage (Table S4), also displayed genotype and sex-dependent differences. The homolog composition in the blood, brain, and liver was significantly different between $F_{W T}$ and $\mathrm{F}_{\mathrm{KO}}$ mice (Table S7 and S11). Differences in the homolog composition of $\mathrm{M}_{\mathrm{WT}}$ and $\mathrm{M}_{\mathrm{KO}}$ mice were only observed in the liver. Sex differences in the homolog profiles were observed in the blood and liver of WT mice and the brain of KO mice.

The changes in the homolog mass profiles translated into sex and genotype-dependent differences in wet weight-adjusted homolog levels. Pronounced changes were observed for $\mathrm{F}_{\mathrm{WT}}$ and $\mathrm{F}_{\mathrm{KO}}$ mice (Fig. 1, Table S7, and S11). Levels of tetra- $(p=0.0128)$ and 
pentachlorinated PCBs $(p=0.0163)$ were lower, and levels of heptachlorinated PCBs $(p=0.0189)$ were higher in blood from $\mathrm{F}_{\mathrm{WT}}$ mice compared to $\mathrm{F}_{\mathrm{KO}}$ group (Fig. 1a2, Table S11). Moreover, levels of tetra-, penta-, hexa-, and heptachlorinated PCBs were lower in the brain of $F_{W T}$ than $F_{K O}$ mice (Fig. 1a3, Table S11). For example, levels of pentachlorinated PCBs in the brain of $\mathrm{F}_{\mathrm{KO}}$ mice were $1,110 \pm 70 \mathrm{ng} / \mathrm{g}$ tissue, which is almost 2-fold higher than the levels in $\mathrm{F}_{\mathrm{WT}}$ mice (630 $\pm 70 \mathrm{ng} / \mathrm{g}$ tissue) (Table $\mathrm{S} 7$ ).

Consistent with the higher $\Sigma$ PCB levels described above, the levels of all homolog groups were more elevated in the liver of $\mathrm{F}_{\mathrm{KO}}$ compared to $\mathrm{F}_{\mathrm{WT}}$ mice $(p \unlhd$.0020). Similarly, the levels of all PCB homologs were higher in $\mathrm{M}_{\mathrm{KO}}$ vs. $\mathrm{M}_{\mathrm{WT}}$ mice $(p \unlhd 0.0374)$.

\subsubsection{Distribution of РСВ Classes in tissues from different exposure groups}

and Aroclor 1254-Although lower chlorinated PCBs are generally more rapidly metabolized than higher chlorinated PCBs, the metabolism and elimination of PCBs also depend on the chlorine substitution pattern (Birnbaum, 1985). Therefore, we compared differences in the mass percentage of PCBs congeners with a 4-, 3,4-, and 3,4,5- substitution pattern and zero or one ortho chlorine substituent (Class A); PCB congeners with two or more ortho chlorine substituents and a 2,4- or 2,3,4- substitution pattern (Class B); PCBs congeners with a 2,4,5-substitution pattern (Class C); and PCB congeners that are considered to be episodic because they are rapidly eliminated following exposure (Imsilp and Hansen, 2005). Class D congeners have adjacent, unsubstituted C-atoms and, typically, contain a 2-, 2,3-, 2,5- and 2,3,6-substitution pattern in at least one phenyl ring (Class D) (Haraguchi et al., 2005; Matthews and Tuey, 1980). Overall, the mass percentage of PCBs belonging to Class $\mathrm{C}$ increased relative to Aroclor 1254 in all tissues from all four exposure groups (Fig. 1; Table S5).

We also observed significant differences in the distribution of PCB Classes, expressed both as tissue levels (Fig. 1; Table S8) and weight percentage (Table S5), by genotype and sex. For example, the levels (Fig. 1) and weight percentage (Table S5) of more persistent PCBs (i.e., Classes A, B, and C) appeared to be higher in the blood and brain of WT compared to $\mathrm{KO}$ mice. When comparing levels in $\mathrm{F}_{\mathrm{WT}}$ and $\mathrm{F}_{\mathrm{KO}}$ mice, this difference was statistically significant for Class A PCBs in the brain $(p=0.0096)$, for Class B and Class C PCBs in the blood ( $p=0.0319$ and $p=0.0333$, respectively), and for Class D PCBs in the blood ( $p=0.0044$ ) and the brain $(p<0.0001)$.

\subsubsection{Distribution of $\mathrm{PCB}$ congeners in adipose tissue from different}

exposure groups and Aroclor 1254-Differences in PCB profiles in adipose and other tissues (see below), organized by genotype, and Aroclor 1254 are shown in Fig. 2 (for a comparison of PCB levels by genotype, see Fig. S6; for a comparison of PCB profiles by tissue from mice within an exposure group, see Fig. S7). PCB congener profiles in adipose tissues were different from the PCB profile of Aroclor 1254 ( $\cos \Theta=0.84$ to 0.88; Table S15). In contrast, PCB profiles in adipose tissue were quite similar across all four exposure groups ( $\cos \Theta=0.97$ to 1.0; Table S16), with the most pronounced difference observed between $\mathrm{F}_{\mathrm{WT}}$ and $\mathrm{F}_{\mathrm{KO}}$ mice. Further analysis of individual PCB congeners revealed minor genotype and, for some congeners, sex-dependent differences in the adipose tissue (Fig. 2a). Persistent PCB congeners, for example, PCB 118 (Class A) and PCB 180 (Class C), 
contained a relatively higher percentage in adipose tissue from WT mice. In contrast, PCB congeners belonging to Class D, such as PCB 70, PCB 95, and PCB 136, showed the opposite trend, with lower percentages of these $\mathrm{PCB}$ congeners being present in the adipose tissue from WT compared to KO mice. Moreover, the percentage of many Class D congeners were lower in $\mathrm{F}_{\mathrm{WT}}$ mice compared to the other exposure groups.

Analysis of the PCB congener composition, based on tissue wet weights, revealed significant differences only between $\mathrm{F}_{\mathrm{WT}}$ and $\mathrm{F}_{\mathrm{KO}}$ mice ( $p<0.001$; Table $\mathrm{S} 9$ and S13). Consistent with the changes in the mass profiles, tissue levels of PCB 70, a Class D congener, were lower in $\mathrm{F}_{\mathrm{WT}}$ than $\mathrm{F}_{\mathrm{KO}}$ mice $(600 \pm 200 \mathrm{ng} / \mathrm{g}$ and 1,100 $\pm 300 \mathrm{ng} / \mathrm{g}$, respectively; $p=0.0142$ ), whereas levels of PCB 180 , a Class $C$ congener, were higher in $\mathrm{F}_{\mathrm{WT}}$ than $\mathrm{F}_{\mathrm{KO}}$ mice $(250 \pm 90 \mathrm{ng} / \mathrm{g}$ vs. $120 \pm 20 \mathrm{ng} / \mathrm{g}$, respectively; $p=0.0307)$.

\subsubsection{Distribution of $\mathrm{PCB}$ congeners in whole blood from different exposure groups and Aroclor 1254-The main PCB congeners detected in blood from WT and} KO mice are also frequently found in human serum (Grimm et al., 2015; Sethi et al., 2019). The overall PCB congener profiles in blood were different from Aroclor $1254(\cos \Theta=0.72$ to 0.74; Table S15) and revealed minor genotype-dependent differences in the blood ( $\cos \Theta$

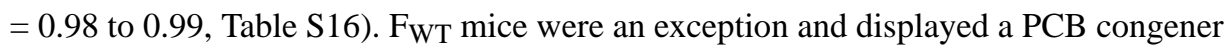
profile that was different from the profiles observed in the blood from the other exposure groups ( $\cos \Theta=0.92$ to 0.97 ). A comparison of the wet weight-based PCB congener composition also revealed statistically significant differences between $\mathrm{F}_{\mathrm{WT}}$ and $\mathrm{F}_{\mathrm{KO}}$ mice $(p<0.0001)$ and $\mathrm{F}_{\mathrm{WT}}$ and $\mathrm{M}_{\mathrm{WT}}$ mice $(p<0.0001)$ (Table S14).

The percentage of some congeners (e.g., PCB 70) was higher in KO compared to WT mice (Fig. 2b). Different congeners (e.g., PCB 99 and PCB 180) had a lower percentage in KO compared to WT mice. In the blood from $\mathrm{F}_{\mathrm{WT}}$ mice, $\mathrm{PCB}$ congeners belonging to Class $\mathrm{D}$ were present at a lower mass percentage, and more persistent PCB congeners from Classes $\mathrm{A}, \mathrm{B}$, and $\mathrm{C}$ were present at a higher mass percentage compared to $\mathrm{M}_{\mathrm{WT}}, \mathrm{F}_{\mathrm{KO}}$, and $\mathrm{M}_{\mathrm{KO}}$. Similar trends between KO and WT mice were observed for these congeners when comparing PCB levels adjusted for wet weight (Fig. S6b). For example, PCB 95 levels, expressed on a wet weight basis, were lower in the blood from $\mathrm{F}_{\mathrm{WT}}$ mice $(8 \pm 1 \mathrm{ng} / \mathrm{g})$ compared to $\mathrm{F}_{\mathrm{KO}}(14 \pm 3 \mathrm{ng} / \mathrm{g} ; p=0.0034)$ and $\mathrm{M}_{\mathrm{WT}}$ mice $(13 \pm 3 \mathrm{ng} / \mathrm{g} ; p=0.0163)$.

\subsubsection{Distribution of $\mathrm{PCB}$ congeners in the brain from different exposure groups and Aroclor 1254-PCB 118, PCBs 132/153, and PCB 138 were major PCB} congeners detected in the brain of WT and KO mice. These PCBs were also prevalent PCB congeners detected in the brain from postnatal day 31 rats exposed to Aroclor 1254 throughout development via the maternal (Yang et al., 2009). PCB 138, PCB 153, and PCB 118 were also major PCB congeners in postmortem human brain samples (Dewailly et al., 1999; Mitchell et al., 2012). Unlike the present study, these studies analyzed a small set of PCB congeners and, thus, provide limited insights into the congener profiles present in the rodent or human brain.

PCB residues in the brain from all exposure groups were distinctively different from the Aroclor 1254 profile ( $\cos \Theta=0.80$ to 0.86 ; Table S15) and showed genotype and sex- 
dependent differences ( $\cos \Theta=0.96$ to 0.99; Table S16) (Fig. 2c). A comparison of the wet weight-based $\mathrm{PCB}$ congener composition also revealed statistically significant differences between $\mathrm{F}_{\mathrm{WT}}$ and $\mathrm{F}_{\mathrm{KO}}$ mice $(p<0.0001)$ and $\mathrm{F}_{\mathrm{KO}}$ and $\mathrm{M}_{\mathrm{KO}}$ mice $(p<0.0001)$ (Table S14). Based on their mass percentage and tissue wet weights, many congeners belonging to Class $\mathrm{D}$ (e.g., $\mathrm{PCB}$ 136) were lower in $\mathrm{F}_{\mathrm{WT}}$ mice compared to the other exposure groups, especially $\mathrm{F}_{\mathrm{KO}}$ mice, an observation that is toxicologically relevant. For example, PCB 95 and PCB 136 are potent sensitizers of the ryanodine receptors (Pessah et al., 2006), cellular targets implicated in PCB-induced developmental neurotoxicity (Holland et al., 2016; Pessah et al., 2010; Pessah et al., 2019). PCB mixtures (i.e., Aroclor 1254) and PCB 95 display a non-monotonic dose-response relationship in rodent studies of PCB developmental neurotoxicity (Wayman et al., 2012; Yang et al., 2009). Thus, depending on the experimental design and the dose, relatively small differences in the levels of neurotoxic PCB congeners in the developing brain may significantly affect neurotoxic outcomes. In the present study, levels of PCB 95 and PCB 136 were 1.4- and 3.0-fold higher in the brain from $\mathrm{F}_{\mathrm{KO}}$ compared to $\mathrm{F}_{\mathrm{WT}}$ mice, respectively ( $p<0.0001$ and $p<0.0001$, respectively; Tables $\mathrm{S} 9$ and 14).

\subsubsection{Distribution of $\mathrm{PCB}$ congeners in the liver from different exposure} groups and Aroclor 1254-PCB profiles in the liver were different from the profile observed for Aroclor 1254 (Fig. 2d) ( $\cos \Theta=0.77$ to 0.88; Table S15). A comparison of PCB congener profiles in the liver of $\mathrm{M}_{\mathrm{WT}}, \mathrm{M}_{\mathrm{KO}}$, and $\mathrm{F}_{\mathrm{KO}}$ mice showed only small differences ( $\cos \Theta=0.97$ to 1.0; Table S16). As with blood and brain tissue, more pronounced differences were observed for $\mathrm{F}_{\mathrm{WT}}$ mice compared to the other exposure groups ( $\cos \Theta=0.92$ to 0.93; Table S16). A comparison of the PCB congener composition, expressed as tissue weight-adjusted tissue levels, revealed significant differences between KO and WT mice of the same sex ( $p<0.001$ for both male and female mice). Moreover, levels of individual PCB congeners were always higher in KO compared to WT mice, irrespective of the sex, because of the higher fat and protein content of the liver of KO mice (Fig. S6d) (Gu et al., 2005; Gu et al., 2003; Weng et al., 2005).

There were also differences in the PCB congener composition between male and female mice of the same genotype ( $p=0.0430$ and $p<0.0001$ when comparing WT and KO mice, respectively) (Table S14). Female mice tended to have higher levels of specific PCB congeners in the liver than male mice of the same genotype ( $p>0.05$; Tables S9 and S13). These differences are consistent with the increased susceptibility of female mice to PCBinduced hepatotoxicity (Wahlang et al., 2019).

\subsubsection{Factors contributing to sex and genotype-dependent differences in the} PCB tissue distribution-The shifts in the composition of PCB homologs, Classes, and individual congeners are driven by several factors. As discussed above, the liver-specific deletion of CPR changes the liver composition in $\mathrm{KO}$ mice, thus resulting in a pronounced accumulation of PCBs in the liver of KO mice. Besides, many of the observed changes in the PCB profiles in tissues are due to the more rapid metabolism of lower chlorinated PCBs, in particular congeners belonging to Class D, in both WT and KO mice (Lucier et al., 1978; Matthews and Anderson, 1975). A relative decrease in lower chlorinated PCBs and an 
increase in higher chlorinated PCB in WT compared to KO mice is consistent with the impaired hepatic metabolism caused by the lack of CPR activity in the liver KO mice (Weng et al., 2005; Wu et al., 2015). Besides, differences in the initial distribution and redistribution of PCBs to the adipose tissue, as well as their (extrahepatic) metabolism (Saghir et al., 1999), likely contribute to subtle differences in the PCB distribution at the time point investigated.

Our study also observed subtle sex differences in the disposition of PCBs, especially in WT mice. Such sex differences, especially in the liver (Fig. 1), are consistent with the higher expression of Cyp2b10, a cytochrome P450 isoform implicated in the metabolism on PCB congeners belonging to Class D (Wu et al., 2013a), and other hepatic and extrahepatic cytochrome P450 enzymes in the female compared to the male mouse liver (Renaud et al., 2011). Indeed, PCB 136 is more rapidly oxidized in precision-cut tissue slices from male compared to female rats (Wu et al., 2013b). However, no sex-dependent differences in PCB levels have been reported in earlier disposition studies in rodents after developmental PCB exposure (Dziennis et al., 2008; Kania-Korwel et al., 2017; Miller et al., 2010; Yang et al., 2009). Alternatively, sex differences in the wet weight-adjusted PCB levels in the liver may be due to different fat content in the liver of female vs. male mice or other factors that we could not account for this the present study.

\subsection{Differences in PCB profiles in tissues from the same exposure group}

Laboratory and biomonitoring studies generally assume that the profiles and levels of PCB in the blood approximate tissue profiles and levels. For example, the distribution of PCBs in juvenile rats shows that serum levels are predictive of liver levels (Soontornchat et al., 1994); however, studies that investigate the congener-specific distribution of PCBs across tissues are limited, especially for lower chlorinated PCBs. In the present study, PCB profiles displayed modest differences between tissues within each exposure group, as shown in heatmaps organized by tissue (Fig. S7). Tissue-to-tissue similarity coefficients ranged from 0.85 to 0.98 (Table S17; Fig. S7). Several other animal studies also reported modest intertissue differences in the PCB profiles after oral or inhalation exposure ( $\cos \Theta \geq 0.80)$ (Hu et al., 2015; Hu et al., 2012; Kodavanti et al., 1998). These comparisons support the assumption that PCB profiles in the blood are a reasonable approximation of PCB tissue profiles in mice and other mammals.

sPLS-DA was used to investigate differences in the PCB profiles across tissues within the same exposure group (Fig. 3; Figs. S8-S10). sPLS-DA comparing the PCB congener profiles from $\mathrm{F}_{\mathrm{WT}}$ mice showed clear groupings according to tissue, with three principal components (PCs) accounting for $84.6 \%$ of the data variance (Fig. 3). PC1 separated adipose tissue from the brain and liver. Based on their loadings, $\mathrm{PCB}$ congeners belonging to Class D (i.e., PCB 52 and PCB 70) were higher in adipose tissue, but lower in brain and liver. PCBs belonging to Class B (i.e., PCB 138) and Class C (i.e., PCB 146 and PCB 183) made a lower contribution to the $\mathrm{PCB}$ profile in adipose tissue, but a higher contribution in the brain and liver. PC2 separated blood from adipose tissue, with some Class D congener (i.e., PCB 139/149 and PCB 151) being higher in blood, but lower in adipose tissue and liver. PC3 separated the liver from other tissues because of lower relative levels of Class D congeners 
(i.e., PCBs 134/143 and PCB 136). Similar differences in the PCB congener profiles across tissues were observed for the other exposure groups despite the impaired hepatic metabolism in KO mice (Figs. S8-S10). Overall, differences in the PCB congener profiles across tissues from mice from the same exposure group were due to differences in the percentage of metabolically more labile PCB congeners (Class D) compared to congeners resistant to metabolites (Class A through $\mathrm{C}$ ). In addition, time-course experiments suggest that the initial distribution vs. redistribution from highly perfused to storage tissues also influences how PCB congener profiles change over time (Birnbaum, 1983; Hu et al., 2010).

\subsection{Tissue-to-blood distribution of PCBs within each exposure group}

Tissue : blood ratios, a measure of how much PCB is distributed from the blood into a target tissue, followed the rank order adipose : blood (median: 201; range: 12-841) > liver : blood (median: 22; range: 7-213) > brain : blood (median: 11; range: 3-34) in WT mice. This rank order is consistent with other studies in mice and other mammalian models (Lutz et al., 1984). The differences between liver : blood vs. brain : blood partition coefficients were more pronounced in $\mathrm{KO}$ mice because of the higher lipid content in the liver, with adipose : blood (median: 71; range: 40-470) liver : blood (median: 91; range 47-481) >> brain : blood (median: 5; range 3-28). With the exception of the liver : blood partition coefficients in $\mathrm{KO}$ mice, the partition coefficients in this study are within the range of partition coefficients observed in animal studies and in humans (Lutz et al., 1984; Wolff et al., 1982). For example, adipose to plasma partition coefficients of $24 \mathrm{PCB}$ congeners in occupationally exposed individuals ranged from 50 to 370 (Wolff et al., 1982).

The partitioning of PCBs between tissues and blood changed with increasing degree of chlorination. For example, tetra- to hexachlorinated PCBs appeared to have a much higher affinity for adipose tissue than higher chlorinated homologs in $\mathrm{F}_{\mathrm{WT}}$ mice at the time point investigated (Fig. 4). The opposite was true for the brain, where the partitioning into the brain appeared to increase with an increase in chlorination. The partitioning of PCBs from the blood into the liver from $\mathrm{F}_{\mathrm{WT}}$ mice seemed to be comparable across homolog groups. Similar trends were observed for $\mathrm{M}_{\mathrm{WT}}, \mathrm{M}_{\mathrm{KO}}$, and $\mathrm{F}_{\mathrm{KO}}$ mice (Figs. S11-S13). The decrease in the adipose : blood partitioning by the homolog group is unexpected based on a structurebased model of the tissue-to-blood partitioning of PCBs (Parham et al., 1997). Besides, the partitioning of individual congeners from the blood into tissues was congener-specific and displayed considerable variability (Figs. $4 \mathrm{a}-\mathrm{c}$ ). Thus, congener specific differences in the blood-to-tissue partitioning exist at specific time points that may influence toxic outcomes following PCB exposure. These differences are not captured when, as discussed above, only PCB profiles are compared between tissues. Especially systematic studies of tissue : blood ratios in human postmortem samples remain limited (Artacho-Cordón et al., 2015; Ploteau et al., 2016; Whitcomb et al., 2005), and further congener-specific studies are needed, especially for lower chlorinated PCB congeners that, unlike persistent legacy PCBs, are still inadvertently produced and represent a current public health concern (Grimm et al., 2015).

\subsection{Comparison of the experimental and theoretical tissue-to-blood distribution of PCBs}

The theoretical tissue : blood ratios, determined with a published model (Endo et al., 2013), are shown for all 209 PCB congeners in Fig. 4d. The model did not predict the congener- 
specific variability of the partition coefficients. Moreover, the model predicted an increase, not a decrease in the adipose : blood ratios with increasing degree of chlorination. These differences between the calculated and experimental values are not entirely surprising because the model does not take structural features into account that, for example, influence the rate of metabolism of individual PCB congeners. Moreover, individual PCBs probably had not reached steady-state levels in our study. Although PCBs, like other lipophilic compounds, are expected to readily partition into the brain, the model overestimated the partitioning of PCBs into the brain. Similarly, earlier studies noted that the levels of PCBs in the brain are lower than expected based on the lipid content of the brain due to the unique lipid composition of the brain (Bachour et al., 1998; Dewailly et al., 1999). Besides, the distribution on PCB 153 in the rat brain is not uniform (Saghir et al., 2000). These differences in local PCB levels could also be due to brain region-specific variations in the tissue composition.

Despite these differences, the predicted and experimental partition coefficients were in reasonable agreement with each other (i.e., deviations were within one order of magnitude, Fig. 4e) and matched the calculated adipose : blood partition coefficients in rats (Endo et al., 2013). The model correctly predicted the more pronounced partitioning of PCBs into the liver of KO mice, as indicated by the distinct clusters of the liver : blood partition coefficients of KO vs. WT mice in Fig. 4e. While not perfect, composition-based models are, therefore, an effective tool to approximate tissue levels based on blood PCB levels, which are experimentally more accessible, especially in humans. However, more detailed, PCB congener-specific studies of the PCB levels in human tissues and blood from the same donors are needed to establish whether or not the model used in our research also allows a rough estimate of PCB tissue levels based on experimentally determined blood levels. Additional work is also necessary to better predict the partitioning of PCBs into brain tissues.

\section{Conclusions}

The present study investigated how an altered hepatic metabolism and a fatty liver caused by the liver-specific deletion of cytochrome P450 reductase affect PCB distribution in mice. The KO mouse model used in this study was developed for research on the role of hepatic metabolism on the systemic toxicity of toxicants; however, the impaired hepatic metabolism also results in a fatty liver and other compensatory changes in the liver and other organs. The impaired hepatic metabolism affected the disposition of PCBs, consistent with earlier studies with individual PCB congeners. However, the altered composition of the liver had a much more prominent effect on the distribution of PCBs, with wet weight-adjusted PCB levels being similar in the liver and adipose tissue from KO mice. In contrast, PCB levels followed the rank order adipose > liver in WT mice. This observation demonstrates that compensatory changes in genetic models can result in an altered disposition of toxicants, such as PCBs, and represent a potential pitfall of genetic models for mechanistic toxicity studies. It is, therefore, essential to assess the disposition of a toxicant when working with a genetic model. In silico approaches, for example, the composition-based model used in this study, represent a time and cost-effective alternative to the measurement of the levels of a toxicant. Despite the difference in the experimental and theoretical partition ratios, our model 
provided a reasonable approximation of the partition coefficients of all 209 PCB congeners and predicted the more pronounced accumulation of PCBs in the liver of KO mice. This approach can be used to approximate the distribution of PCBs into the liver of genetic steatosis models, such as ob/ob mice, and diet-induced obesity models and, thus, aid in the interpretation of toxicity studies with PCBs and other lipophilic compounds.

\section{Supplementary Material}

Refer to Web version on PubMed Central for supplementary material.

\section{Acknowledgments}

The authors thank Dr. Xinxin Ding (University of Arizona, Tucson, Arizona) for providing the mouse model.

Funding sources

This work was supported by grants ES027169, ES013661, and ES005605 from the National Institute of Environmental Health Sciences, National Institutes of Health.

\section{References}

Ampleman MD, Martinez A, DeWall J, Rawn DF, Hornbuckle KC, Thorne PS, 2015 Inhalation and dietary exposure to PCBs in urban and rural cohorts via congener-specific measurements. Environ. Sci. Technol 49, 1156-1164. [PubMed: 25510359]

Artacho-Cordón F, Fernández-Rodríguez M, Garde C, Salamanca E, Iribarne-Durán LM, Torné P, Expósito J, Papay-Ramírez L, Fernández MF, Olea N, Arrebola JP, 2015 Serum and adipose tissue as matrices for assessment of exposure to persistent organic pollutants in breast cancer patients. Environ. Res 142, 633-643. [PubMed: 26318258]

ATSDR, 2000 Toxicological Profile for Polychlorinated Biphenyls (PCBs). https://www.atsdr.cdc.gov/ toxprofiles/tp.asp?id=142\&tid=26.

Bachour G, Failing K, Georgii S, Elmadfa I, Brunn H, 1998 Species and organ dependence of PCB contamination in fish, foxes, roe deer, and humans. Arch. Environ. Contam. Toxicol 35, 666-673. [PubMed: 9776785]

Birnbaum LS, 1983 Distribution and excretion of 2,3,6,2',3',6'- and 2,4,5,2',4',5'-hexachlorobiphenyl in senescent rats. Toxicol. Appl. Pharmacol 70, 262-272. [PubMed: 6414105]

Birnbaum LS, 1985 The role of structure in the disposition of halogenated aromatic xenobiotics. Environ. Health Perspect 61, 11-20. [PubMed: 2998745]

Chen JJ, Chen GS, Bunce NJ, 2003 Inhibition of CYP 1A2-dependent MROD activity in rat liver microsomes: An explanation of the hepatic sequestration of a limited subset of halogenated aromatic hydrocarbons. Environ. Toxicol 18, 115-119. [PubMed: 12635099]

Chen X, Lin Y, Dang K, Puschner B, 2017 Quantification of polychlorinated biphenyls and polybrominated diphenyl ethers in commercial cows' milk from California by gas chromatographytriple quadruple mass spectrometry. PLoS One 12, e0170129. [PubMed: 28085917]

Chong J, Soufan O, Li C, Caraus I, Li S, Bourque G, Wishart DS, Xia J, 2018 MetaboAnalyst 4.0: towards more transparent and integrative metabolomics analysis. Nucleic Acids Res. 46, W486W494. [PubMed: 29762782]

Chu I, Villeneuve DC, Yagminas A, Lecavalier P, Poon R, Feeley M, Kennedy SW, Seegal RF, Hakansson H, Ahlborg UG, Valli VE, 1994 Subchronic toxicity of 3,3',4,4',5-pentachlorobiphenyl in the rat. 1. Clinical, biochemical, hematological, and histopathological changes. Fundam. Appl. Toxicol 22, 457-468. [PubMed: 8050640]

Davis JC, 1986 Statistics and Data Analysis in Geology. Wiley, New York. 
Dewailly E, Mulvad G, Pedersen HS, Ayotte P, Demers A, Weber JP, Hansen JC, 1999 Concentration of organochlorines in human brain, liver, and adipose tissue autopsy samples from Greenland. Environ. Health Perspect 107, 823-828.

Diliberto JJ, Burgin DE, Birnbaum LS, 1999 Effects of CYP1A2 on disposition of 2,3,7,8tetrachlorodibenzo-p-dioxin, 2,3,4,7,8-pentachlorodibenzofuran, and 2,2',4,4',5,5' hexachlorobiphenyl in CYP1A2 knockout and parental (C57BL/6N and 129/Sv) strains of mice. Toxicol. Appl. Pharmacol 159, 52-64. [PubMed: 10448125]

Dziennis S, Yang D, Cheng J, Anderson KA, Alkayed NJ, Hurn PD, Lein PJ, 2008 Developmental exposure to polychlorinated biphenyls influences stroke outcome in adult rats. Environ. Health Perspect 116, 474-480. [PubMed: 18414629]

Endo S, Bauerfeind J, Goss KU, 2012 Partitioning of neutral organic compounds to structural proteins. Environ. Sci. Technol 46, 12697-12703. [PubMed: 23102204]

Endo S, Brown TN, Goss KU, 2013 General model for estimating partition coefficients to organisms and their tissues using the biological compositions and polyparameter linear free energy relationships. Environ. Sci. Technol 47, 6630-6639. [PubMed: 23672211]

Endo S, Escher BI, Goss KU, 2011 Capacities of membrane lipids to accumulate neutral organic chemicals. Environ. Sci. Technol 45, 5912-5921. [PubMed: 21671592]

Endo S, Goss KU, 2011 Serum albumin binding of structurally diverse neutral organic compounds: data and models. Chem. Res. Toxicol 24, 2293-2301. [PubMed: 22070391]

Frame GM, 1997 A collaborative study of 209 PCB congeners and 6 Aroclors on 20 different HRGC columns .2. Semi-quantitative Aroclor congener distributions. Fresenius J. Anal. Chem 357, 714722.

Geisler A, Endo S, Goss KU, 2012 Partitioning of organic chemicals to storage lipids: elucidating the dependence on fatty acid composition and temperature. Environ. Sci. Technol 46, 9519-9524. [PubMed: 22849558]

Grimm FA, Hu D, Kania-Korwel I, Lehmler HJ, Ludewig G, Hornbuckle KC, Duffel MW, Bergman A, Robertson LW, 2015 Metabolism and metabolites of polychlorinated biphenyls. Crit. Rev. Toxicol 45, 245-272. [PubMed: 25629923]

Gu J, Cui H, Behr M, Zhang L, Zhang Q-Y, Yang W, Hinson JA, Ding X, 2005 In vivo mechanisms of tissue-selective drug toxicity: effects of liver-specific knockout of the NADPH-cytochrome P450 reductase gene on acetaminophen toxicity in kidney, lung, and nasal mucosa. Mol. Pharmacol 67, 623-630. [PubMed: 15550675]

Gu J, Weng Y, Zhang QY, Cui H, Behr M, Wu L, Yang W, Zhang L, Ding X, 2003 Liver-specific deletion of the NADPH-cytochrome P450 reductase gene: impact on plasma cholesterol homeostasis and the function and regulation of microsomal cytochrome P450 and heme oxygenase. J. Biol. Chem 278, 25895-25901. [PubMed: 12697746]

Haga Y, Suzuki M, Matsumura C, Okuno T, Tsurukawa M, Fujimori K, Kannan N, Weber R, Nakano T, 2018 Monitoring OH-PCBs in PCB transport worker's urine as a non-invasive exposure assessment tool. Environ. Sci. Poll. Res 25, 16446-16454.

Hansen LG, Welborn ME, 1977 Distribution, dilution, and elimination of polychlorinated biphenyl analogs in growing swine. J. Pharm. Sci 66, 497-501. [PubMed: 404418]

Haraguchi K, Koga N, Kato Y, 2005 Comparative metabolism of polychlorinated biphenyls and tissue distribution of persistent metabolites in rats, hamsters, and guinea pigs. Drug Metab. Dispos 33, 373-380. [PubMed: 15608140]

Holland EB, Feng W, Zheng J, Dong Y, Li X, Lehmler H-J, Pessah IN, 2016 An extended structureactivity relationship of non-dioxin-like PCBs evaluates and supports modeling predictions and identifies picomolar potency of PCB 202 towards ryanodine receptors. Toxicol. Sci 155, 170-181. [PubMed: 27655348]

Hu X, Adamcakova-Dodd A, Lehmler H-J, Hu D, Kania-Korwel I, Hornbuckle KC, Thorne PS, 2010 Time course of congener uptake and elimination in rats after short-term inhalation exposure to an airborne polychlorinated biphenyl (PCB) mixture. Environ. Sci. Technol 44, 6893-6900. [PubMed: 20698547] 
Hu X, Adamcakova-Dodd A, Lehmler HJ, Gibson-Corley K, Thorne PS, 2015 Toxicity evaluation of exposure to an atmospheric mixture of polychlorinated biphenyls by nose-only and whole-body inhalation regimens. Environ. Sci. Technol 49, 11875-11883. [PubMed: 26348937]

Hu X, Adamcakova-Dodd A, Lehmler HJ, Hu D, Hornbuckle K, Thorne PS, 2012 Subchronic inhalation exposure study of an airborne polychlorinated biphenyl mixture resembling the Chicago ambient air congener profile. Environ. Sci. Technol 46, 9653-9662. [PubMed: 22846166]

Hu X, Lehmler HJ, Adamcakova-Dodd A, Thorne PS, 2013 Elimination of inhaled 3,3'dichlorobiphenyl and the formation of the 4-hydroxylated metabolite. Environ. Sci. Technol 47, 4743-4751. [PubMed: 23582014]

Imsilp K, Hansen L, 2005 PCB profiles in mouse skin biopsies and fat from an environmental mixture. Environ. Toxicol. Pharmacol 19, 71-84. [PubMed: 21783463]

Kania-Korwel I, Barnhart CD, Stamou M, Truong KM, El-Komy MH, Lein PJ, Veng-Pedersen P, Lehmler H-J, 2012 2,2',3,5',6-Pentachlorobiphenyl (PCB 95) and its hydroxylated metabolites are enantiomerically enriched in female mice. Environ. Sci. Technol 46, 11393-11401. [PubMed: 22974126]

Kania-Korwel I, El-Komy MHME, Veng-Pedersen P, Lehmler H-J, 2010 Clearance of polychlorinated biphenyl atropisomers is enantioselective in female C57B1/6 mice. Environ. Sci. Technol 44, 2828-2835. [PubMed: 20384376]

Kania-Korwel I, Hornbuckle KC, Peck A, Ludewig G, Robertson LW, Sulkowski WW, Espandiari P, Gairola CG, Lehmler H-J, 2005 Congener specific tissue distribution of Aroclor 1254 and a highly chlorinated environmental PCB mixture in rats. Environ. Sci. Technol 39, 3513-3520. [PubMed: 15954224]

Kania-Korwel I, Hrycay EG, Bandiera SM, Lehmler H-J, 2008 2,2',3,3',6,6'-Hexachlorobiphenyl (PCB 136) atropisomers interact enantioselectively with hepatic microsomal cytochrome P450 enzymes. Chem. Res. Toxicol 21, 1295-1303. [PubMed: 18494506]

Kania-Korwel I, Lukasiewicz T, Barnhart CD, Stamou M, Chung H, Kelly KM, Bandiera S, Lein PJ, Lehmler H-J, 2017 Congener-specific disposition of chiral polychlorinated biphenyls in lactating mice and their offspring: Implications for PCB developmental neurotoxicity. Toxicol. Sci 158, 101-115. [PubMed: 28431184]

Kania-Korwel I, Shaikh NS, Hornbuckle KC, Robertson LW, Lehmler H-J, 2007 Enantioselective disposition of PCB 136 (2,2',3,3',6,6'-hexachlorobiphenyl) in C57BL/6 mice after oral and intraperitoneal administration. Chirality 19, 56-66. [PubMed: 17089340]

Kennedy MW, Carpentier NK, Dymerski PP, Kaminsky LS, 1981 Metabolism of dichlorobiphenyls by hepatic microsomal cytochrome P-450. Biochem. Pharmacol 30, 577-588. [PubMed: 6791661]

Kodavanti PRS, Ward TR, Derr-Yellin EC, Mundy WR, Casey AC, Bush B, Tilson HA, 1998 Congener-specific distribution of polychlorinated biphenyls in brain regions, blood, liver, and fat of adult rats following repeated exposure to Arcolor 1254. Toxicol. Appl. Pharmacol 153, 199210. [PubMed: 9878591]

Lê Cao K-A, Boitard S, Besse P, 2011 Sparse PLS discriminant analysis: biologically relevant feature selection and graphical displays for multiclass problems. Bmc Bioinformatics 12, 253. [PubMed: 21693065]

Li X, Holland EB, Feng W, Zheng J, Dong Y, Pessah IN, Duffel MW, Robertson LW, Lehmler H-J, 2018 Authentication of synthetic environmental contaminants and their (bio)transformation products in toxicology: polychlorinated biphenyls as an example. Environ. Sci. Poll. Res 25, $16508-16521$.

Li X, Wu X, Kelly KM, Veng-Pedersen P, Lehmler H-J, 2019 Toxicokinetics of chiral PCB 136 and its hydroxylated metabolites in mice with a liver-specific deletion of cytochrome $\mathrm{P} 450$ reductase. Chem. Res. Toxicol 32, 727-736. [PubMed: 30729780]

Li X, Zhang C, Wang K, Lehmler H-J, 2020 Datasets: Fatty liver and impaired hepatic metabolism alters the congener-specific distribution of polychlorinated biphenyls (PCBs) in mice with a liverspecific deletion of cytochrome P450 reductase. 10.25820/data.006117.

Lucier GW, McDaniel OS, Schiller CM, Matthews HB, 1978 Structural requirements for the accumulation of chlorinated biphenyl metabolites in the fetal rat intestine. Drug Metab. Dispos 6, 584-590. [PubMed: 30609] 
Lutz RJ, Dedrick RL, Tuey D, Sipes IG, Anderson MW, Matthews HB, 1984 Comparison of the pharmacokinetics of several polychlorinated biphenyls in mouse, rat, dog, and monkey by means of a physiological pharmacokinetic model. Drug Metab. Dispos 12, 527-535. [PubMed: 6149901]

Martinez A, Hornbuckle KC, 2011 Record of PCB congeners, sorbents and potential toxicity in core samples in Indiana Harbor and Ship Canal. Chemosphere 85, 542-547. [PubMed: 21899876]

Matthews HB, Anderson MW, 1975 Effect of chlorination on the distribution and excretion of polychlorinated biphenyls. Drug Metab. Dispos 3, 371-380. [PubMed: 241618]

Matthews HB, Tuey DB, 1980 The effect of chlorine position on the distribution and excretion of four hexachlorobiphenyl isomers. Toxicol. Appl. Pharmacol 53, 377-388. [PubMed: 6770494]

Milanowski B, Lulek J, Lehmler H-J, Kania-Korwel I, 2010 Assessment of the disposition of chiral polychlorinated biphenyls in female mdr $1 \mathrm{a} / \mathrm{b}$ knockout versus wild-type mice using multivariate analyses. Environ. Int 36, 884-892. [PubMed: 19923000]

Miller VM, Kahnke T, Neu N, Sanchez-Morrissey SR, Brosch K, Kelsey K, Seegal RF, 2010 Developmental PCB exposure induces hypothyroxinemia and sex-specific effects on cerebellum glial protein levels in rats. Int. J. Dev. Neurosci 28, 553-560. [PubMed: 20691776]

Mitchell MM, Woods R, Chi LH, Schmidt RJ, Pessah IN, Kostyniak PJ, LaSalle JM, 2012 Levels of select PCB and PBDE congeners in human postmortem brain reveal possible environmental involvement in 15q11-q13 duplication autism spectrum disorder. Environ. Mol. Mutagen 53, 589598. [PubMed: 22930557]

Parham FM, Kohn MC, Matthews HB, DeRosa C, Portier CJ, 1997 Using structural information to create physiologically based pharmacokinetic models for all polychlorinated biphenyls. I. Tissue:blood partition coefficients. Toxicol. Appl. Pharmacol 144, 340-347. [PubMed: 9194418]

Pencikova K, Svrzkova L, Strapacova S, Neca J, Bartonkova I, Dvorak Z, Hyzdalova M, Pivnicka J, Palkova L, Lehmler HJ, Li X, Vondracek J, Machala M, 2018 In vitro profiling of toxic effects of prominent environmental lower-chlorinated PCB congeners linked with endocrine disruption and tumor promotion. Environ. Pollut 237, 473-486. [PubMed: 29518658]

Pessah IN, Cherednichenko G, Lein PJ, 2010 Minding the calcium store: Ryanodine receptor activation as a convergent mechanism of PCB toxicity. Pharmacol. Ther 125, 260-285. [PubMed: 19931307]

Pessah IN, Hansen LG, Albertson TE, Garner CE, Ta TA, Do Z, Kim KH, Wong PW, 2006 Structureactivity relationship for noncoplanar polychlorinated biphenyl congeners toward the ryanodine receptor- $\mathrm{Ca}^{2+}$ channel complex type 1 (RyR1). Chem. Res. Toxicol 19, 92-101. [PubMed: 16411661]

Pessah IN, Lein PJ, Seegal RF, Sagiv SK, 2019 Neurotoxicity of polychlorinated biphenyls and related organohalogens. Acta Neuropathol. 138, 363-387. [PubMed: 30976975]

Ploteau S, Antignac J-P, Volteau C, Marchand P, Vénisseau A, Vacher V, Le Bizec B, 2016 Distribution of persistent organic pollutants in serum, omental, and parietal adipose tissue of French women with deep infiltrating endometriosis and circulating versus stored ratio as new marker of exposure. Environ. Int 97, 125-136. [PubMed: 27575367]

Renaud HJ, Cui JY, Khan M, Klaassen CD, 2011 Tissue distribution and gender-divergent expression of 78 cytochrome P450 mRNAs in mice. Toxicol. Sci 124, 261-277. [PubMed: 21920951]

Saghir SA, Hansen LG, Holmes KR, Kodavanti PRS, 2000 Differential and nonuniform tissue and brain distribution of two distinct ${ }^{14} \mathrm{C}$-hexachlorobiphenyls in weanling rats. Toxicol. Sci 54,60 70. [PubMed: 10746932]

Saghir SA, Koritz GD, Hansen LG, 1999 Short Term Distribution, Metabolism, and Excretion of 2,2',5-Tri-, 2,2',4,4'-Tetra-, and 3,3',4,4'-Tetrachlorobiphenyls in Prepubertal Rats. Arch. Environ. Contam. Toxicol 36, 213-220. [PubMed: 9888968]

Schecter A, Colacino J, Haffner D, Patel K, Opel M, Papke O, Birnbaum L, 2010 Perfluorinated compounds, polychlorinated biphenyls, and organochlorine pesticide contamination in composite food samples from Dallas, Texas, USA. Environ. Health Perspect 118, 796-802. [PubMed: 20146964]

Schmitt W, 2008 General approach for the calculation of tissue to plasma partition coefficients. Toxicol. in Vitro 22, 457-467. [PubMed: 17981004] 
Sethi S, Morgan RK, Peng W, Lin YP, Li XS, Luna C, Koch M, Bansal R, Duffel MW, Puschner B, Zoeller RT, Lehmler HJ, Pessah IN, Lein PJ, 2019 Comparative analyses of the 12 most abundant PCB congeners detected in human maternal serum for activity at the thyroid hormone receptor and ryanodine receptor. Environ. Sci. Technol 53, 3948-3958. [PubMed: 30821444]

Soontornchat S, Li MH, Cooke PS, Hansen LG, 1994 Toxicokinetic and toxicodynamic influences on endocrine disruption by polychlorinated biphenyls. Environ. Health Perspect 102, 568-571. [PubMed: 9679117]

Spindler-Vomachka M, Vodicnik MJ, 1984 Distribution of 2,4,5,2',4',5'-hexachlorobiphenyl among lipoproteins during pregnancy and lactation in the rat. J. Pharmacol. Exp. Ther 230, 263-268. [PubMed: 6431076]

Van Birgelen APJM, Van der Kolk J, Fase KM, Bol I, Poiger H, Brouwer A, Van den Berg M, 1994 Toxic potency of 3,3',4,4',5-pentachlorobiphenyl relative to and in combination with 2,3,7,8tetrachlorodibenzo-p-dioxin in a subchronic feeding study in the rat. Toxicol. Appl. Pharmacol 127, 209-221. [PubMed: 8048064]

van Noort PC, Haftka JJ, Parsons JR, 2010 Updated Abraham solvation parameters for polychlorinated biphenyls. Environ. Sci. Technol 44, 7037-7042. [PubMed: 20738135]

Wahlang B, Falkner KC, Gregory B, Ansert D, Young D, Conklin DJ, Bhatnagar A, McClain CJ, Cave M, 2013 Polychlorinated biphenyl 153 is a diet-dependent obesogen that worsens nonalcoholic fatty liver disease in male C57BL6/J mice. Journal of Nutritional Biochemistry 24, 1587-1595. [PubMed: 23618531]

Wahlang B, Jin J, Hardesty JE, Head KZ, Shi H, Falkner KC, Prough RA, Klinge CM, Cave MC, 2019 Identifying sex differences arising from polychlorinated biphenyl exposures in toxicant-associated liver disease. Food Chem Toxicol 129, 64-76. [PubMed: 31026535]

Wahlang B, Song M, Beier JI, Cameron Falkner K, Al-Eryani L, Clair HB, Prough RA, Osborne TS, Malarkey DE, States JC, Cave MC, 2014 Evaluation of Aroclor 1260 exposure in a mouse model of diet-induced obesity and non-alcoholic fatty liver disease. Toxicol Appl Pharmacol 279, 380 390. [PubMed: 24998970]

Wayman GA, Yang D, Bose DD, Lesiak A, Ledoux V, Bruun D, Pessah IN, Lein PJ, 2012 PCB-95 promotes dendritic growth via ryanodine receptor-dependent mechanisms. Environ. Health Perspect 120, 997-1002. [PubMed: 22534141]

Weisbrod AV, Shea D, Moore MJ, John JJ, 2000 Bioaccumulation patterns of polychlorinated biphenyls and chlorinated pesticides in Northwest Atlantic pilot whales. Environ. Toxicol. Chem 19, 667-677.

Weng Y, DiRusso CC, Reilly AA, Black PN, Ding X, 2005 Hepatic gene expression changes in mouse models with liver-specific deletion or global suppression of the NADPH-cytochrome P450 reductase gene. Mechanistic implications for the regulation of microsomal cytochrome $\mathrm{P} 450$ and the fatty liver phenotype. J. Biol. Chem 280, 31686-31698. [PubMed: 16006652]

Whitcomb BW, Schisterman EF, Buck GM, Weiner JM, Greizerstein H, Kostyniak PJ, 2005 Relative concentrations of organochlorines in adipose tissue and serum among reproductive age women. Environmental Toxicology and Pharmacology 19, 203-213. [PubMed: 21783478]

Wolff MS, Thornton J, Fischbein A, Lilis R, Selikoff IJ, 1982 Disposition of polychlorinated biphenyl congeners in occupationally exposed persons. Toxicol. Appl. Pharmacol 62, 294-306. [PubMed: 6800066]

Wu L, Gu J, Weng Y, Kluetzman K, Swiatek P, Behr M, Zhang QY, Zhuo X, Xie Q, Ding X, 2003 Conditional knockout of the mouse NADPH-cytochrome P450 reductase gene. Genesis 36, 177181. [PubMed: 12929087]

Wu X, Barnhart C, Lein PJ, Lehmler HJ, 2015 Hepatic metabolism affects the atropselective disposition of 2,2',3,3',6,6'-hexachlorobiphenyl (PCB 136) in mice. Environ. Sci. Technol 49, 616-625. [PubMed: 25420130]

Wu X, Duffel M, Lehmler H-J, 2013a Oxidation of polychlorinated biphenyls by liver tissue slices from phenobarbital-pretreated mice is congener-specific and atropselective. Chem. Res. Toxicol 26, 1642-1651. [PubMed: 24107130]

Wu X, Kania-Korwel I, Chen H, Stamou M, Dammanahalli KJ, Duffel M, Lein PJ, Lehmler H-J, 2013b Metabolism of 2,2',3,3',6,6'-hexachlorobiphenyl (PCB 136) atropisomers in tissue slices 
from phenobarbital or dexamethasone-induced rats is sex-dependent. Xenobiotica 43, 933-947. [PubMed: 23581876]

Wu X, Zhai G, Schnoor JL, Lehmler H-J, 2020 Atropselective disposition of 2,2',3,4',6pentachlorobiphenyl (PCB 91) and identification of its metabolites in mice with liver-specific deletion of cytochrome P450 reductase. Chem. Res. Toxicol 33, 1328-1338. [PubMed: 31403789]

Wyss PA, Muehlebach S, Bickel MH, 1982 Pharmacokinetics of 2,2',4,4',5,5'-hexachlorobiphenyl (6$\mathrm{CB}$ ) in rats with decreasing adipose tissue mass. I. Effects of restricting food intake two weeks after administration of 6-CB. Drug Metab. Dispos 10, 657-661. [PubMed: 6130918]

Yang D, Kim KH, Phimister A, Bachstetter AD, Ward TR, Stackman RW, Mervis RF, Wisniewski AB, Klein SL, Kodavanti PR, Anderson KA, Wayman G, Pessah IN, Lein PJ, 2009 Developmental exposure to polychlorinated biphenyls interferes with experience-dependent dendritic plasticity and ryanodine receptor expression in weanling rats. Environ. Health Perspect 117, 426-435. [PubMed: 19337518]

Zhao H, Adamcakova-Dodd A, Hu D, Hornbuckle KC, Just CL, Robertson LW, Thorne PS, Lehmler H-J, 2010 Development of a synthetic PCB mixture resembling the average polychlorinated biphenyl profile in Chicago air. Environ. Int 36, 819-827. [PubMed: 19375801] 


\section{Highlights}

- $\quad$ Fatty liver and impaired hepatic metabolism alter PCB tissue distribution in mice

- $\quad$ PCBs accumulate in the liver of cytochrome P450 reductase-null mice

- $\quad$ Tissue partitioning of PCBs does not always increase with degree of chlorination

- Composition-based models approximate the magnitude of PCBs' tissue partitioning 
(a1) Adipose

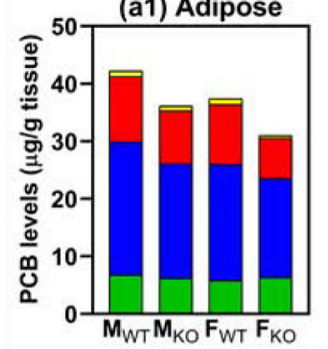

(b1) Adipose

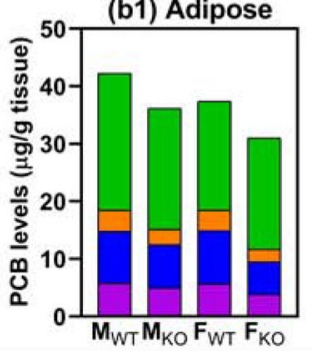

(a2) Blood

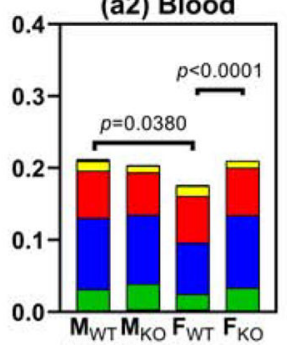

(b2) Blood

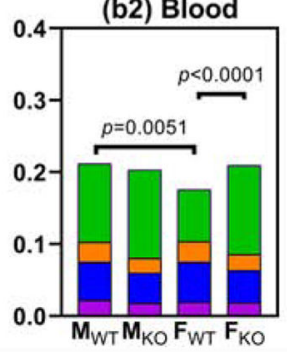

(a3) Brain

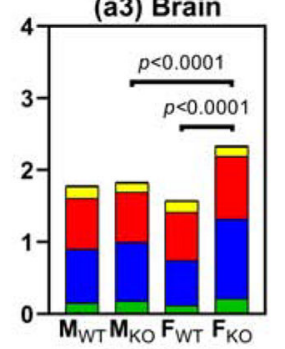

(b3) Brain

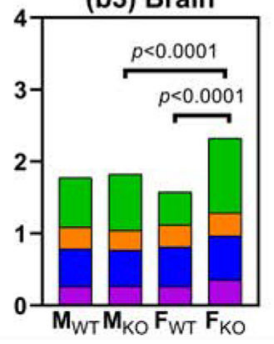

(a4) Liver

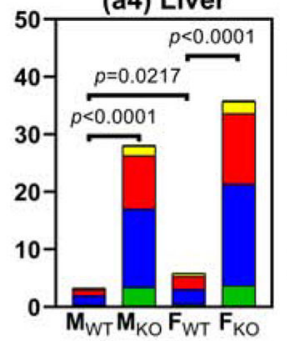

(b4) Liver

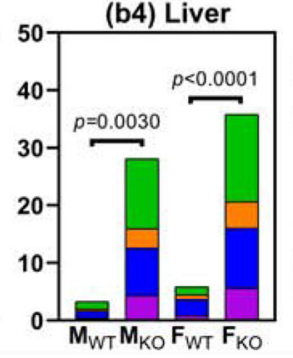

(a5) Arolcor

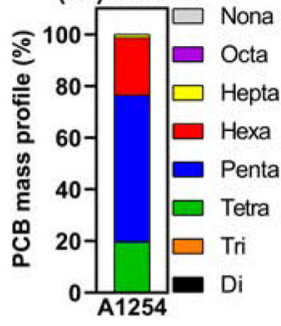

(b5) Arolcor

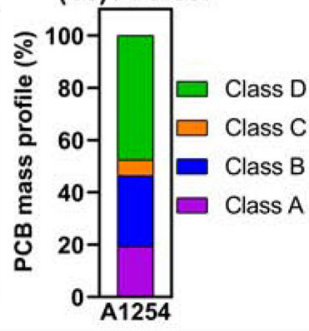

Fig. 1.

PCB homolog composition, based on PCB homolog tissue levels ( $\mu \mathrm{g} / \mathrm{g}$ wet weight), in (a1) adipose, (a2) blood, (a3) brain, and (a4) liver and PCB Class composition in (b1) adipose, (b2) blood, (b3) brain, and (b4) liver showed statistically significant genotype and sexdependent differences, as determined using two-way ANOVA. Total PCB levels ( $\mathrm{PPCB}$, $\mu \mathrm{g} / \mathrm{g}$ wet weight) showed statistically significant differences between WT and KO mice in the male liver $(\mathrm{p}=0.0010)$, female liver $(\mathrm{p}=0.0004)$, and female brain $(\mathrm{p}=0.0002)$ (Table $\mathrm{S} 13)$. The composition of Aroclor 1254 by homolog group and Class is shown for comparison in panels (a5) and (b5). Class A: PCBs congeners with a 4-, 3,4-, and 3,4,5substitution pattern and zero or one ortho chlorine substituent. Class B: PCB congeners with two or more ortho chlorine substituents and a 2,4- or 2,3,4- substitution pattern. Class C: PCBs congeners with a 2,4,5-substitution pattern. Class D: PCB congeners with, in contrast to Classes A through $\mathrm{C}$, are readily metabolized and, for example, a 2-, 2,3-, 2,5- and 2,3,6substitution pattern in at least one phenyl ring (Haraguchi et al., 2005). Levels of PCB congeners were measured by GC-MS in tissues from male wild-type $\left(\mathrm{M}_{\mathrm{WT}}, \mathrm{n}=3\right)$, male knockout $\left(\mathrm{M}_{\mathrm{KO}}, \mathrm{n}=5\right)$, female wild-type $\left(\mathrm{F}_{\mathrm{WT}}, \mathrm{n}=4\right)$, and female knockout $\left(\mathrm{F}_{\mathrm{KO}}, \mathrm{n}=4\right)$ mice exposed orally to Aroclor 1254. 

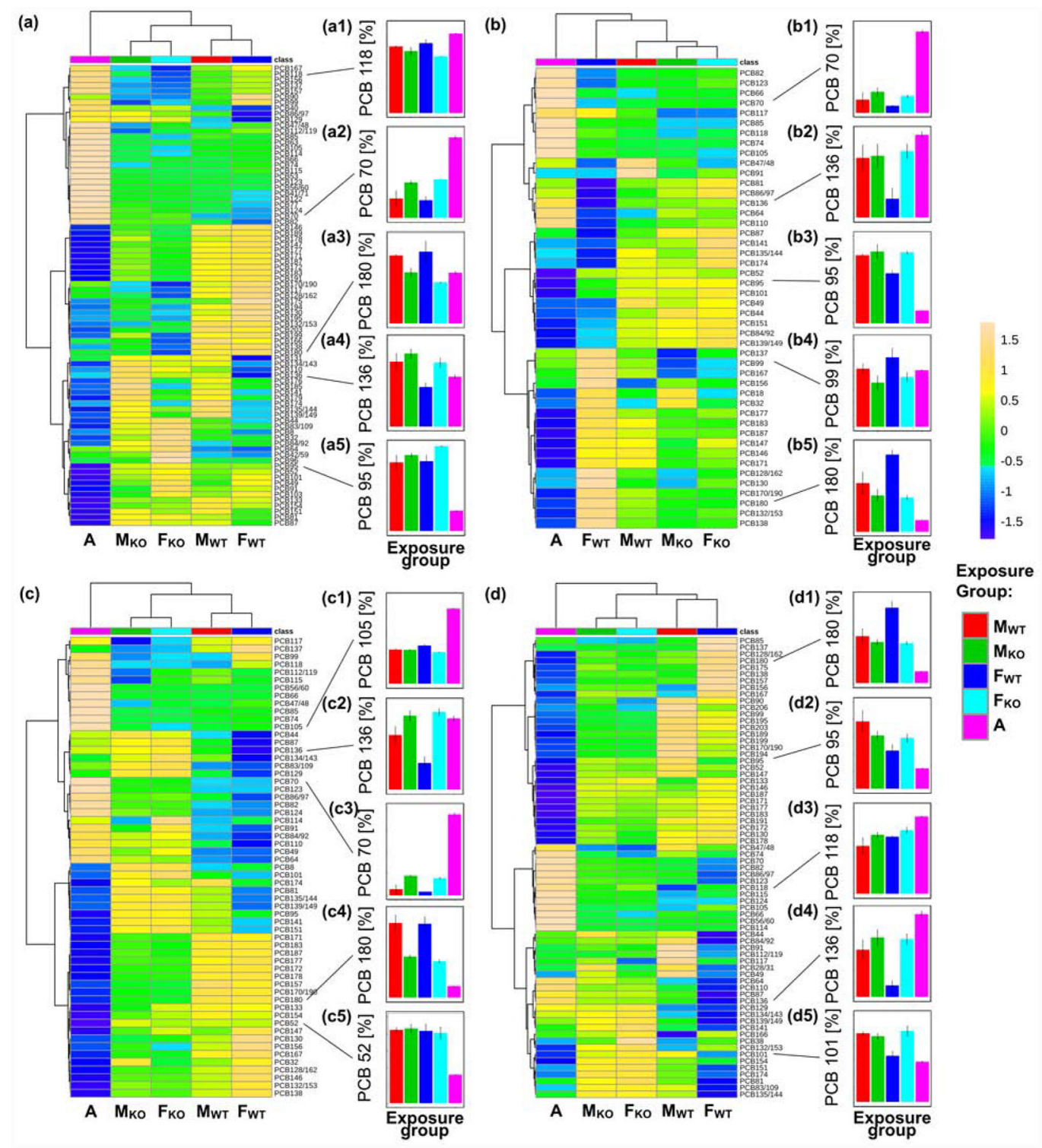

Group:

Fig. 2.

A comparison of the PCB congener profiles in (a) adipose tissue, (b) blood, (c) brain and (d) liver from male wild-type $\left(\mathrm{M}_{\mathrm{WT}}, \mathrm{n}=3\right)$, male knockout $\left(\mathrm{M}_{\mathrm{KO}}, \mathrm{n}=5\right)$, female wild-type ( $\mathrm{F}_{\mathrm{WT}}$, $n=4)$, and female knockout $\left(F_{K O}, n=4\right)$ mice reveals genotype-dependent differences in the distribution of individual PCB congeners in these tissues. The congener profile of Aroclor 1254 is shown for comparison. The small panels illustrate differences in the mass percentages of representative PCB congeners. These congeners shown here were selected because they illustrate specific differences in the mass composition and, in most cases, are also toxicologically relevant. Heatmaps were generated after removing features with $>25 \%$ missing values and autoscaling features of the original data using the Heatmap function as implement by MetaboAnalyst 4.0 (Chong et al., 2018). For PCB congener profiles and tissue levels, see the Supplementary material or (Li et al., 2020), respectively. A, Aroclor 1254. 


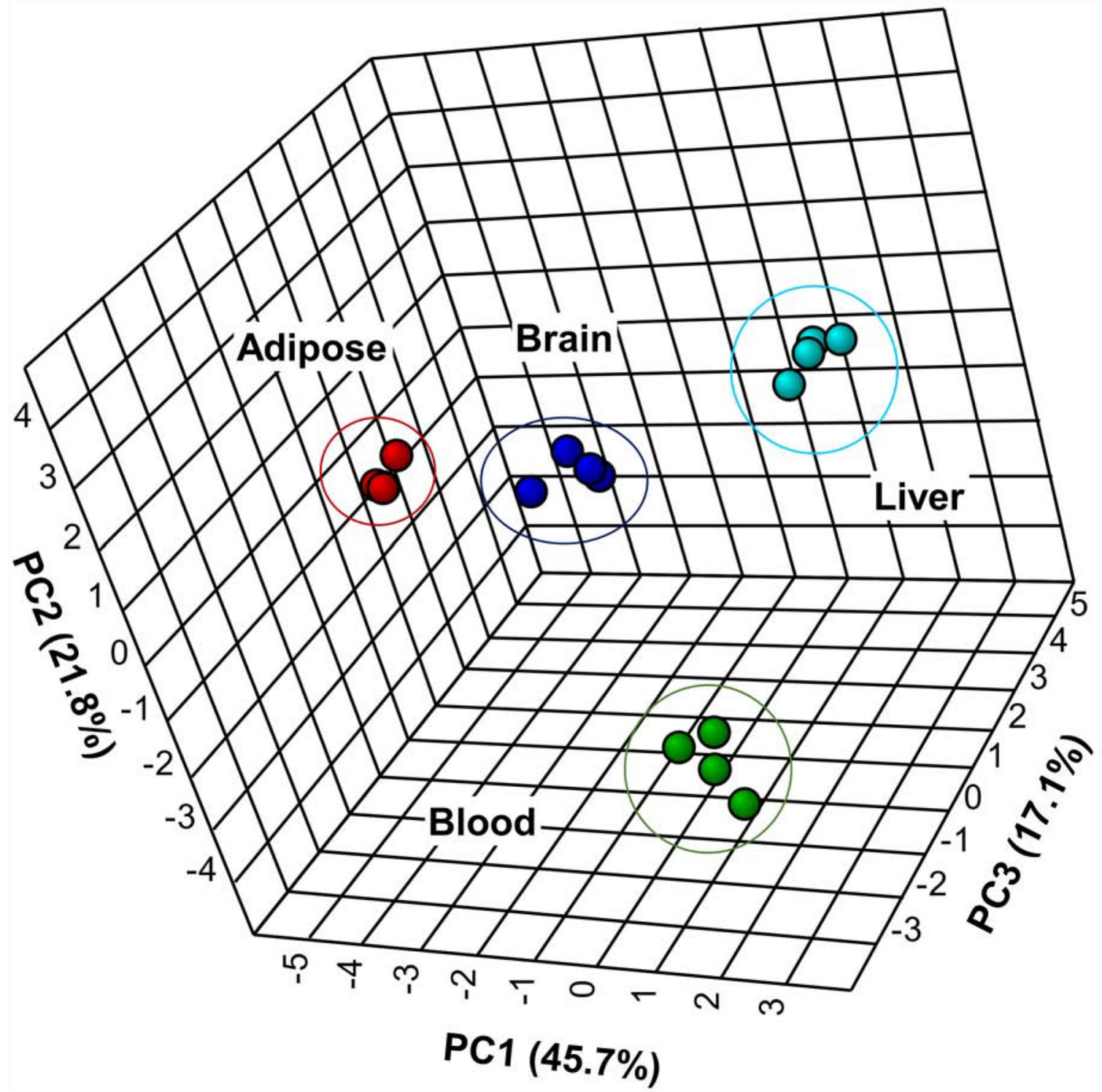

Fig. 3.

Sparse partial least squares - discriminant analysis (sPLS-DA)(Lê Cao et al., 2011) revealed differences in the PCB congener profiles between tissues from $\mathrm{F}_{\mathrm{WT}}$ mice $(\mathrm{n}=4)$, with three principal components (PCs) accounting for $84.6 \%$ of the data variance. These differences were due to tissue-specific changes in the relative levels of PCB congeners that are more readily metabolized (Class D) vs. PCB congeners that are more resistant to metabolism (Classes A through C). PC1 separated adipose tissue from the brain and liver; PC2 separated blood from adipose tissue; PC3 separated the liver from other tissues. sPLS-DA was performed with PCB congener profiles using MetaboAnalyst 4.0 after removing variables for a threshold of 25\%, cubic root transformation, and autoscaling features (Chong et al., 2018). For analogous analyses of PCB congener profiles from $M_{\mathrm{WT}}, \mathrm{M}_{\mathrm{KO}}$, and $\mathrm{F}_{\mathrm{KO}}$ mice, see Figs. S8-S10 in the Supplementary material. 

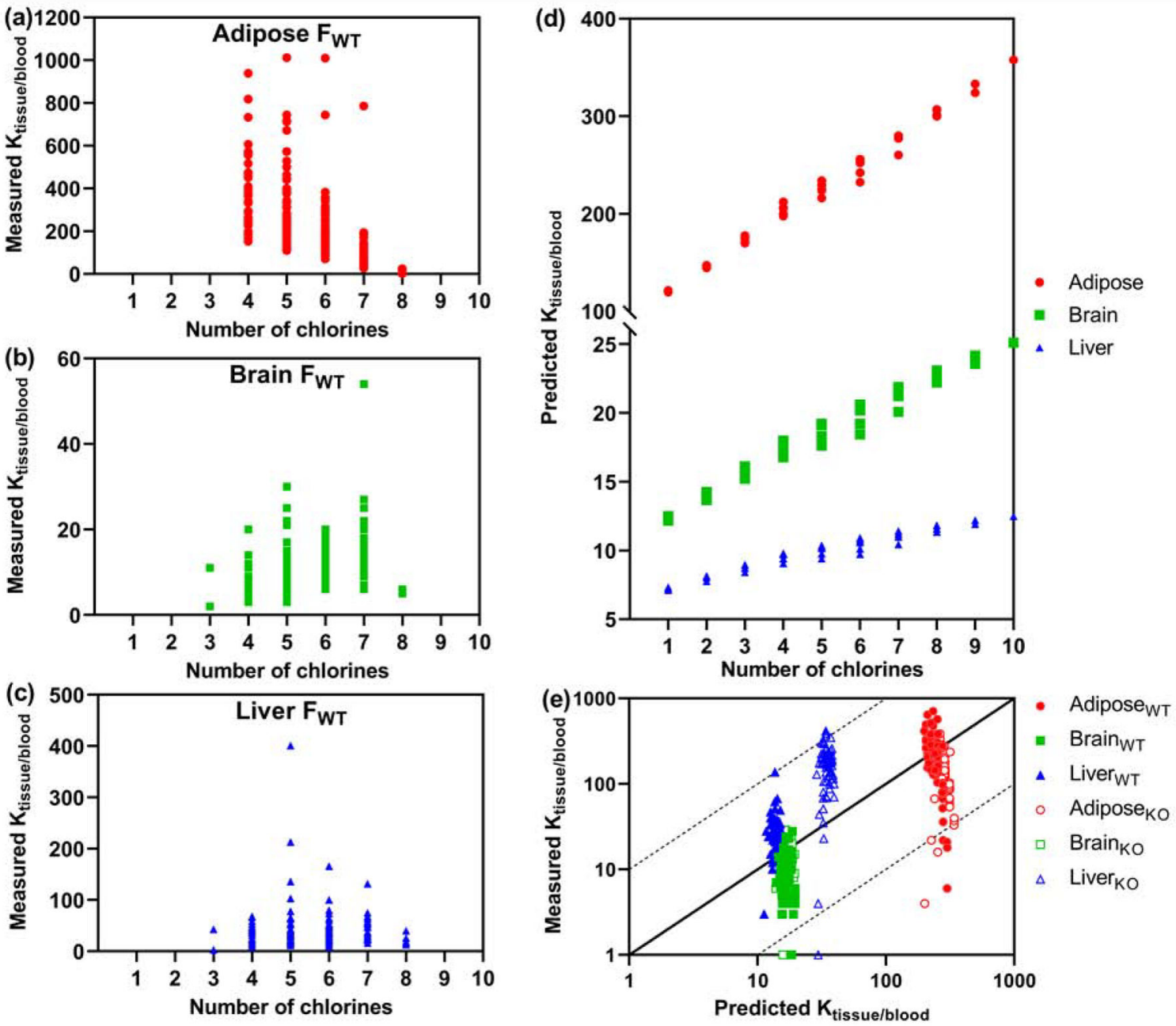

Fig. 4.

Tissue : blood ratios $\left(\mathrm{K}_{\text {tissue/blood }}(\mathrm{ng} / \mathrm{g}) /(\mathrm{ng} / \mathrm{g})\right)$ of different PCB homolog groups in female wild type mice $\left(\mathrm{F}_{\mathrm{WT}}, \mathrm{n}=4\right)$ show different trends with an increasing degree of chlorination: (a) Adipose : blood ratios decrease, (b) brain : blood ratios increase, and (c) liver : blood ratios of PCBs remain comparable with increasing degree of chlorination. Similar trends were observed with all other exposure groups (Figures S11-S13). (d) In contrast to the experimental findings, predicted tissue : blood ratios (i.e., adipose : blood, brain : blood, and liver : blood ratios) increase with an increasing degree of chlorination. Data for the tissue composition were obtained from the literature (Endo et al., 2013). (e) Despite this discrepancy, the predicted tissue : blood ratios are in reasonable agreement with the experimental values (for the underlying tissue composition data, see Table S3). Each symbol represents the tissue : blood ratio of an individual PCB congener ( $\mathrm{Li}$ et al., 2020). 